\title{
UJI IMUNOMODULATOR BEBERAPA SUBFRAKSI EKSTRAK ETIL ASETAT MENIRAN (Phyllanthus niruri [L]) PADA MENCIT PUTIH JANTAN DENGAN METODA CARBON CLEARANCE
}

Yufri Aldi, Nisya Ogiana, Dian Handayani

Fakultas Farmasi, Universitas Andalas, Padang

\begin{tabular}{l}
\hline KATA KUNCI \\
Phyllanthus niruri L., \\
Imunostimulant Effect, \\
Ethyl Acetat, Carbon \\
Clearance method
\end{tabular}

PENDAHULUAN

Sistem imun non spesifik merupakan pertahanan tubuh terdepan dalam menghadapi serangan mikroorganisme, karena memberikan respons langsung terhadap antigen ${ }^{1,2,3}$. Salah satu upaya tubuh untuk mempertahankan diri terhadap masuknya antigen, misalnya bakteri adalah menghancurkan bakteri bersangkutan secara non spesifik dengan proses fagositosis. Makrofag sebagai sel fagosit mononuklear dalam pertahanan seluler non spesifik memegang peranan penting demikian pula neutrofil dan monosit.Sel-sel fagosit tersebut harus berada dalam jarak dekat dengan partikel bakteri, sehingga memungkinkan lepasnya zat atau mediator tertentu yang disebut faktor leukotaktik atau kemotaktik yang berasal dari bakteri ataupun makrofag yang sebelumnya telah berada dilokasi bakteri atau yang dilepaskan oleh komplemen ${ }^{4}$.

Salah satu herba yang dapat dimanfaatkan sebagai peningkat sistem pertahanan tubuh adalah meniran. Meniran adalah herba yang berasal dari genus Phyllanthus dengan nama 
ilmiah Phyllanthus niruri $\mathrm{L}^{5,6}$. Tanaman meniran banyak digunakan untuk hepatitis, infeksi salurankencing, serta untuk merangsang keluarnya air seni (diureticum), untuk penyembuhan diare, infeksi saluran pencernaan dan penyakit yang disebabkan karena gangguanfungsi hati.Buahnya berasa pahit, digunakan untuk luka dan scabies.Akar segar digunakan untuk pengobatan hepatitis. Daun digunakan untuk penambahan nafsu makan dan antipiretik $^{7,8,9}$. Meniran juga mempunyai manfaat sebagai imunostimulan yang dapat memperbaiki sistem imun yang fungsinya terganggu ${ }^{10}$. Secara klinis imunomodulator digunakan pada pasien dengan gangguan imunitas, antara lain pada kasus keganasan HIV/AIDS, malnutrisi, alergi, dan lain-lain ${ }^{11,12,13,14,15,16}$. Berbagai penelitian telah dilakukan menggunakan ekstrak herba meniran, seperti pengujian efek antihiperurisemia ekstrak etanol Phyllanthus niruri L. yang memperlihatkan penghambatan xanthin oxidase secara in vitro dengan $\mathrm{IC}_{50} 39,39$ $\mu \mathrm{g} / \mathrm{mL}^{13}$. Penelitian ekstrak meniran (Phyllanthus niruri L.) mempunyai aktivitas diuretik karena terjadi peningkatan volume urin dan ekskresi $\mathrm{Na}^{+}, \mathrm{K}^{+}, \mathrm{Cl}^{-}$setelah ekstrak kental dari Phyllanthus niruri L. disuntikkan pada tikus albino dosis $200 \mathrm{mg} / \mathrm{kg}$ dan 400 $\mathrm{mg} / \mathrm{kg}$ yang sebelumnya telah diinduksi menggunakan hidroklorthiazid dosis 10 $\mathrm{mg} / \mathrm{kg}^{17,18}$. Penelitian lain tentang kandungan kimia dari Triphala megaext mempunyai efek imunomodulasi yaitu flavonoid, alkaloid, tanin, saponin, glikosida, dan komponen fenolik ${ }^{19}$.

Ekstrak meniran (Phyllanthus niruri L.) memiliki aktivitas melindungi hati dari zat toksik baik berupa parasit, obat-obatan, virus maupun bakteri ${ }^{20}$. Pada penelitian lain menunjukkan bahwa tanaman meniran (Phyllanthus niruri L.) memiliki aktivitas melindungi sel hepatosit hati dari karbon tetraklorida dan sitotoksitas yang diinduksi dengan galaktosamin ${ }^{21}$. Kemudian pada penelitian tentang senyawa filantin dan hipofilantin yang terdapat pada tumbuhan meniran (Phyllanthus amarus) mempunyai aktivitas sebagai antitumor pada dosis 50 $\mathrm{mg} / \mathrm{kg}$ dan $100 \mathrm{mg} / \mathrm{kg}^{22}$. Berdasarkan keterangan dilakukan penelitian tentang uji imunomodulator beberapa subfraksi ekstrak etil asetat meniran (Phyllanthus niruri L.) dengan metoda carbon clearance dan diperoleh perbandingan subfraksi mana yang memiliki aktivitas imunomodulator pada herba Phyllanthus niruri.Metoda carbon clearance digunakan untuk mengukur aktivitas sel-sel fagosit untuk membunuh organisme patogen yang masuk kedalam tubuh.

\section{METODE PENELITIAN}

Alat

Kertas saring, botol coklat, rotary evaporator, kromatografi kolom flash, vial, bejana (chamber) dan plat KLT,desikator, pipet tetes, lampu UV $365 \mathrm{~nm}$, spektrofotometer UV-Vis, alat suntik, gelas 
ukur, timbangan hewan, spatel, jarum oral, timbangan analitik, mikroskop, wadah (botol), lumping, stamfer, kaca objek, gunting bedah.

\section{Bahan}

Herba meniran(Phyllanthus niruri Linn.), $n$ heksan, etil asetat, metanol, etanol, aquadest, pewarna Giemsa, minyak emersi, $\mathrm{NaCl}$ fisiologis, Na-CMC,larutan dapar fosfat, asam asetat $1 \%$ dan mencit putih jantan dengan berat 20-30 g.

\section{Prosedur Kerja}

\section{Pengambilan Herba Meniran}

Meniran (Phyllanthus niruri L.) diambil di Simpang Tanjung, Padang Pariaman, Sumatera Barat. Bagian tanaman meniran yang digunakan herba.

\section{Pembuatan Subfraksi Meniran}

Sebanyak $1.5 \mathrm{~kg}$ sampel kering meniran yang telah bersih dan dirajang halus dimaserasi dengan menggunakan 31 pelarut etil asetat dalam botol coklat selama 5 hari sambil sesekali dikocok. Setelah 5 hari perendaman, diambil maseratnya dengan cara disaring dan perendaman dilanjutkan sampai 3 kali. Gabungan maserat yang didapat diuapkan secara in vacuo sehingga didapat ekstrak kental. Ekstrak kental dilakukan uji kromatografi lapis tipis ${ }^{23}$.

Ekstrak kental dipisahkan berdasarkan peningkatan derajat kepolaran dengan menggunakan alat kromatografi flash.
Dengan membuat campuran silika pereabsorbsi sebanyak 80 g ekstrak kental meniran dan silika pereabsobsi sebanyak 80 $\mathrm{g}$, kemudian in vacuo. Setelah itu masukkan silika gel $100 \mathrm{~g}$ ke dalam kolom yang dibasahi dengan n-heksan. Sediaan preabsorbsi dimasukkan sedikit demi sedikit kedalam kolom aga, kemudian dilakukan elusi dengan menurut metode SGP (step gradien polarity) menggunakan eluen:

\begin{tabular}{c|c}
\hline$n$-heksan $100 \%$ & $1000 \mathrm{~mL}$ \\
\hline$n$-heksan : etil asetat (19:1) & $1000 \mathrm{~mL}$ \\
$n$-heksan : etil asetat $(9: 1)$ & $500 \mathrm{~mL}$ \\
$n$-heksan : etil asetat $(4: 1)$ & $500 \mathrm{~mL}$ \\
$n$-heksan : etil asetat $(2: 1)$ & $500 \mathrm{~mL}$ \\
$n$-heksan : etil asetat $(1: 1)$ & $500 \mathrm{~mL}$ \\
$n$-heksan : etil asetat (1:4) & $500 \mathrm{~mL}$ \\
Etil asetat $100 \%$ & $500 \mathrm{~mL}$ \\
\hline
\end{tabular}

\section{Penyiapan Hewan Percobaan}

Hewan percobaan yang digunakan dalam penelitian adalah mencit putih jantan dengan berat 20-40 gram berumur 2-3 bulan yang dikondisikan selama 1 minggu dalam kandang yang baik untuk menyesuaikan lingkungannya.

\section{Penentuan Dosis}

Dosis tunggal subfraksi meniran yang digunakan yaitu $100 \mathrm{mg} / \mathrm{kg} \mathrm{BB}^{24}$. Penyiapan Sediaan Uji

\section{a.Penyiapan Suspensi Karbon Koloid}

Sebanyak 1,6 g tinta cina yang telah dikeringkan, suspensikan dengan $25 \mathrm{~mL}$ tween $80 \quad(1 \%)$ b/v dalam larutan $\mathrm{NaCl}$ fisiologis $0.9 \%$, sampai didapatkan konsentrasi larutan $64 \mathrm{mg} / \mathrm{mL}^{25}$. 


\section{b. Penetapan Kadar Karbon}

Tinta cina sebanyak $5 \mathrm{~g}$ dimasukkan ke dalam cawan penguap dan diuapkan dalam oven pada suhu $105^{\circ} \mathrm{C}$ selama 30 menit.Pengeringan kemudian dilanjutkan dalam desikator sampai berat konstan.

\section{c. Pembuatan Kurva Baku Karbon}

Tinta cina yang telah dikeringkan lalu ditimbang sebanyak $100 \mathrm{mg}$, didispersikan dalam $100 \mathrm{~mL}$ asam asetat sehingga konsentrasi $1 \mathrm{mg} / \mathrm{mL}$. Masing-masing larutan dipipet sebanyak 2, 3, 4, 5, dan $6 \mathrm{~mL}$, kemudian dicukupkan dengan asam asetat $1 \%$ hingga volume $50 \mathrm{~mL}$, sehingga didapatkan kadar karbon 40, 60, 80, 100, dan $120 \mu \mathrm{g} / \mathrm{mL}$. Dari masing-masing kadar tersebut dipipet sebanyak $4 \mathrm{~mL}$, selanjutnya ditambahkan darah mencit yang diambil dari ujung vena ekor sebanyak $25 \mu \mathrm{L}$. Setelah dihomogenkan, ukur adsorbannya dengan spektrofotometer UV-Vis pada panjang gelombang $650 \mathrm{~nm}$. Plot adsorben yang diperoleh dengan kadar karbon, digunakan untuk membuat kurva kalibrasi. Sebagai blanko digunakan darah mencit dan aquadest saja.

\section{Pengujian Aktivitas Subfraksi Meniran}

\section{a. Uji Bersihan Karbon pada Sel Fagosit}

Mencit dibagi menjadi 9 kelompok dengan dosis tunggal $100 \mathrm{mg} / \mathrm{kgBB}$.Tiap kelompok terdiri dari 5 ekor mencit jantan. Hewan dikelompokkan sebagai berikut:
Kelompok I : diberi sediaan Tween 80

Kelompok II : diberi sediaan suspensisubfraksi 1

Kelompok II : diberi sediaan suspensisubfraksi 2

Kelompok IV : diberi sediaan suspensi subfraksi 3

Kelompok V : diberi sediaan suspensi subfraksi 4

Kelompok VI : diberi sediaan suspense subfraksi 5

Kelompok VII : diberi sediaan suspense subfraksi 6

Kelompok VIII : diberi sediaan suspense subfraksi 7

Kelompok IX : diberi sediaan suspense subfraksi 8

Tiap kelompok diberikan secara oral satu kali sehari selama 6 hari berturut-turut. Setelah pemberian suspensi sampel pada masingmasing kelompok, ujung ekor mencit dipotong dan darah ditampung pada plat tetes yang ditambahkan NaEDTA hingga homogen.Darah diambil $25 \mu \mathrm{l}$ dan dilisis dengan $4 \mathrm{ml}$ asam asetat 1\%.Contoh darah pertama ini dipakai sebagai blanko (menit ke-0). Kemudian $0,1 \mathrm{~mL} / 10 \mathrm{~g}$ BB suspensi karbondisuntikkan secara intravena pada bagian ekor, darah mencit diambil $25 \mu \mathrm{L}$ selama menit ke 3, 6, 9, 12, dan 15 setelah penyuntikkan. Masing-masing darah dilisis dengan $4 \mathrm{ml}$ asam asetat $1 \%$ dan diukur serapannya pada panjang gelombang $650 \mathrm{~nm}$ menggunakan spektrofotometer UV-Vis. 
Setelah dua belas jam, kemudian hewan tersebut dikorbankan dan limfanya diambil untuk ditimbang.

Dihitung konstanta fagositosis (K) dan indeks fagositosis (IF)dengan menggunakan rumus:

$$
(K)=\frac{\log A(n)-\log A(n-1)}{t(n-1)-t(n)}
$$

Keterangan :

$$
\begin{aligned}
& \mathrm{K}=\text { Konstanta fagositosis } \\
& \mathrm{A}=\text { Absorban pada waktu ke- } 0 \\
& \mathrm{t}=\text { Waktu }(3,6,9,12 \text { dan } 15) \\
& \mathrm{n}=\text { Periode pengambilan }(1,2,3,4,) \\
& (\mathrm{IF})=\frac{\text { Konstanta fagositosis mencit } \mathrm{Z}}{\text { Konstantafagositosis rata-rata }}
\end{aligned}
$$

Keterangan:

$$
\begin{aligned}
\text { IF }= & \text { Indeks fagositosis } \\
\text { Mencit } Z= & \text { Mencit yang telah } \\
& \text { diperlakukan dan ditentukan } \\
& \text { harga konstanta } \\
& \text { fagositosisnya }
\end{aligned}
$$

Indeks fagositosis dari tiap kelompok uji dibandingkan dengan kelompok control ${ }^{26,27,28}$

\section{b. Penghitungan Jumlah Sel Leukosit}

Sebanyak $1 \mathrm{~mL}$ darah diteteskan pada kaca objek lalu ratakan dengan kaca objek lain untuk memperoleh lapisan darah homogen, kering anginkan dan tambahkan metanol biarkan 5 menit kemudian ditambahkan larutan Giemsa (encerkan dengan air suling) sebanyak 10 tetes biarkan 20 menit, bilas dengan aquades mengalir dan kering anginkan. Hitung jumlah sel eusinofil, neutrofil batang, limfosit monosit di bawah mikroskop perbesaran 40x dengan menggunakan minyak emersi.

\section{c. Penghitungan Sel Limfosit Limpa}

Timbang $50 \mathrm{mg}$ limpa dari mencit yang telah dikorbankan, kemudian suspensikan ke dalam $3 \mathrm{~mL}$ larutan dapar fosfat $\mathrm{pH}$ 7,4. Suspensi limpa diambil sebanyak $20 \mu \mathrm{L}$ dan diteteskan di atas kaca objek, lalu biarkan mengering. Setelah itu fiksasi dengan metanol selama dua menit, kemudian dibilas dengan aquadest dan dikering anginkan.

Untuk pewarnaan, preparat yang telah difiksasi lalu diwarnai dengan cara meneteskan pewarna Giemsa sebanyak 5 tetes yang sebelumnya telah diencerkan dengan aquadest 1:10. Biarkan kontak selama 5 menit, lalu bilas dengan aquadest, kemudian dikering anginkan.Preparat yang telah diwarnai, dihitung jumlah limfositnya dibawah mikroskop perbesaran 40x dengan menggunakan minyak emersi.

\section{Analisis Data}

Data yang diperoleh dianalisis secara statistik dengan metode analisis variansi(anova) satu arah kemudian dilanjutkan dengan analisis Duncan.

\section{HASIL DAN PEMBAHASAN}

Dari penelitian yang telah dilakukan didapatkan hasil sebagai berikut: 
1. Dari $10 \mathrm{~kg}$ meniran segar diperoleh 1.5 kg sampel kering meniran.

2. Dari $1.5 \mathrm{~kg}$ sampel kering meniran diperoleh ekstrak etil asetat kental sebanyak 178 gram.

3. Dari 178 gram ekstrak etil asetat kental yang dikromatografi kolom diperoleh subfraksi sebanyak :

a. Subfraksi $1 n$ - heksan $100 \% 89,5$ gram

b. Subfraksi $2 n$-heksan : etil asetat (19:1) 8,5 gram

c. Subfraksi $3 n$-heksan : etil asetat (9:1) 4 gram

d. Subfraksi $4 n$-heksan : etil asetat (4:1) 4,2 gram

e. Subfraksi $5 n$-heksan : etil asetat (2:1) 7,6 gram

f. Subfraksi $6 n$-heksan : etil asetat (1:1) 9,7 gram

g. Subfraksi $7 n$-heksan : etil asetat (1:4) 8,3 gram

h. Subfraksi 8 etil asetat 100\%4,5 gram

4. Untuk identifikasi dari semua subfraksi meniran:

Pemerian: warna hijau tua, bau menyengat dan tajam, rasa pahit Kelarutan: praktis tidak larut dalam air

5. Hasil penghitungan kadar karbon tinta cina didapatkan tinta cina dengan kadar karbon $22,46 \%$.

6. Hasil penghitungan kurva kalibrasi karbon diperoleh persamaan linear $\mathrm{y}=$ $0,0058 \mathrm{x}-0.0084$ dengan $\mathrm{r}=0,9940$.
7. Pengukuran nilai adsorban darah mencit putih yang mengandung karbon setelah pemberian beberapa subfraksi meniran selama enam hari dengan dosis tunggal $100 \mathrm{mg} / \mathrm{kg}$ BB diperoleh penurunan berturut-turut setiap selang waktu uji pada masing-masing dosis. Harga indeks fagositosispadasubfraksi 1 , subfraksi 2 , subfraksi 3, subfraksi 4, subfraksi 5, subfraksi 6 , subfraksi 7 , dan subfraksi 8hasilnya lebih besar dari satu (IF $>1$ ). Nilai IF terendah diperoleh pada subfraksi 8 yaitu 1,02654 sedangkan nilai IF tertinggi pada subfraksi 3 yaitu 1,64622 .

8. Penghitungan jumlah komponen sel leukosit darah mencit setelah pemberian beberapa subfraksi meniran selama enam hari, menunjukkan peningkatan jumlah komponen sel leukosit tertinggi pada kelompok subfraksi 3 dengan dosis tunggal $100 \mathrm{mg} / \mathrm{kgBB}$.

9. Penimbangan bobot limpa dan bobot limpa relatif mencit setelah pemberian beberapa subfraksi meniran selama enam hari, menunjukkan peningkatan bobot tertinggi pada subfraksi 3 dengan dosis tunggal $100 \mathrm{mg} / \mathrm{kgBB}$.

10. Penghitungan jumlah sel limfosit pada limpa mencit setelah pemberian beberapa subfraksi meniran dengan dosis tunggal $100 \mathrm{mg} / \mathrm{kgBB}$ selama enam hari, menunjukkan peningkatan jumlah sel pada setiap kelompok subfraksi. 
Ekstrak kental yang di dapat dilakukan uji karakteristik ekstrak menggunakan KLT (romatografi lapis tipis)Hasil KLT dari ekstrak tersebut dapat dilihat Gambar 1.

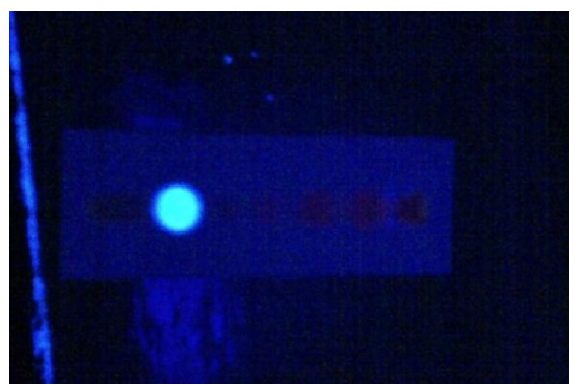

Gambar 1. Hasil KLT dari ekstrak meniran. Dari ekstrak meniran diperoleh 8 subfraksi dengan hasil KLT dapat dilihat Gambar 2

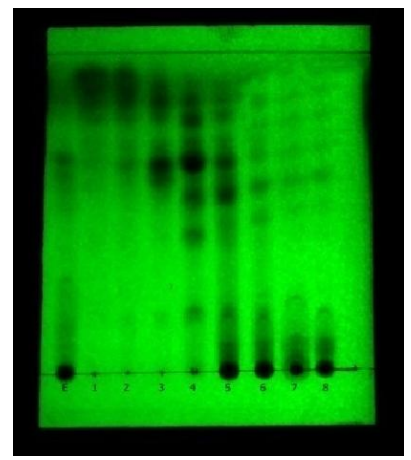

Gambar 2. Hasil KLT dari subfraksi eksrak meniran.

Keterangan Gambar :

E. Ektrak Etil Asetat

1. Subfraksi 1 (n-heksan) $100 \%$

2. Subfraksi 2 ( $n$-heksan:etil asetat) 19:1

3. Subfraksi 3 ( $n$-heksan:etil asetat) 9:1

4. Subfraksi 4 (n-heksan:etil asetat) $4: 1$

5. Subfraksi 5 ( $n$-heksan:etil asetat) $2: 1$

6. Subfraksi 6 ( $n$-heksan:etil asetat) $1: 2$

7. Subfraksi 7 ( $n$-heksan:etil asetat) 1:4

8. Subfraksi 8 (etil asetat) $100 \%$

Nilai absorban diukur dengan spektrofotometer UV-Vis pada panjang gelombang $650 \mathrm{~nm}$, setelah sebelumnya dibuat kurva kalibrasi untuk melihat hubungan linear antara konsentrasi karbon dalam darah dengan nilai absorban. Dari kurva baku tersebut diperoleh persamaan regresi serapan dan konsentrasi karbon yaitu $y=0,0058 x-0,0084$ dengan $r=0,9940$. Hasil tersebut menunjukkan adanya hubungan linier antara konsentrasi karbon dalam darah mencit putih jantan dengan nilai absorban.Semakin tinggi konsentrasi karbon dalam darah maka akan semakin tinggi pula nilai absorban yang diperoleh. Data lengkap dapat dilihat pada Gambar 3.

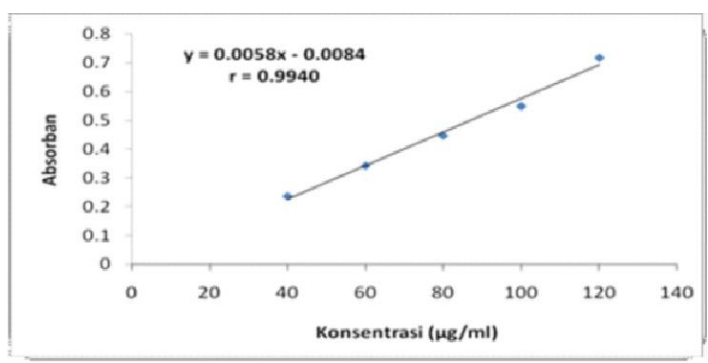

Gambar 3. Nilai absorban dari carbon yang terkandung di dalam darah mencit putih.

Pada penelitian yang dilakukan, terjadi penurunan nilai absorban pada semua kelompok subfraksi dibandingkan dengan kelompok kontrol. Penurunan nilai absorban terbesar pada dosis tunggal $100 \mathrm{mg} / \mathrm{kgBB}$ diperoleh pada subfraksi 3, lalu setelah itu subfraksi 4, subfraksi 5, subfraksi 2, subfraksi 6 , subfraksi 1 , subfraksi 7 , dan subfraksi 8. Semakin menurunnya nilai absorban berarti konsentrasi karbon yang tinggal dalam darah mencit semakin sedikit. Hal ini memperlihatkan bahwa terjadi peningkatan aktivitas fagositosis pada masing-masing kelompok subfraksi. 
Data absorban digunakan untuk menghitung nilai konstanta fagositosis. Konstanta fagositosis merupakan salah satu parameter yang digunakan untuk menentukan kecepatan fagositosis. Semakin besar harga konstanta fagositosis maka semakin tinggi kecepatan bersihan karbon, yang berarti semakin cepat sel fagositik melakukan proses fagositosis seperti terlihat pada Gambar 3. Hal ini menunjukkan adanya pengaruh subfraksi meniran terhadap kecepatan eliminasi karbon di dalam darah mencit.

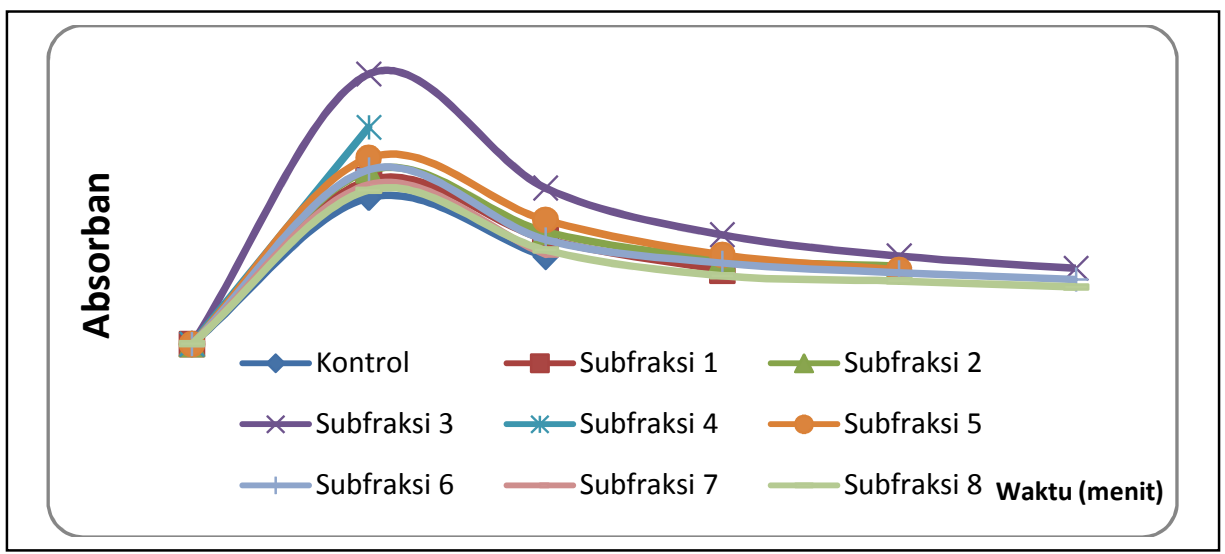

Gambar 3. Grafik konstanta fagositosis dari darah mencit setelah pemberian subfraksi meniran (Phylanthus niruri Linn.) selama 6 hari.

Berdasarkan harga konstanta fagositosis diperoleh nilai indeks fagositosis yang digunakan sebagai parameter pengujian aktivitas imunomodulator.Nilai rata-rata indeks fagositosis menunjukkan aktivitas fagositosis sel-sel fagositik terhadap partikel karbon sebagai antigen akibat pengaruh pemberian subfraksi meniran.Apabila nilai rata-rata indeks fagositosis lebih besar dari satu (IF >1) menunjukkan zat uji tersebut mempunyai kemampuan imunostimulan dan nilai indek fagositosis dapat dilihat Gambar $4^{4,29,30,31}$.

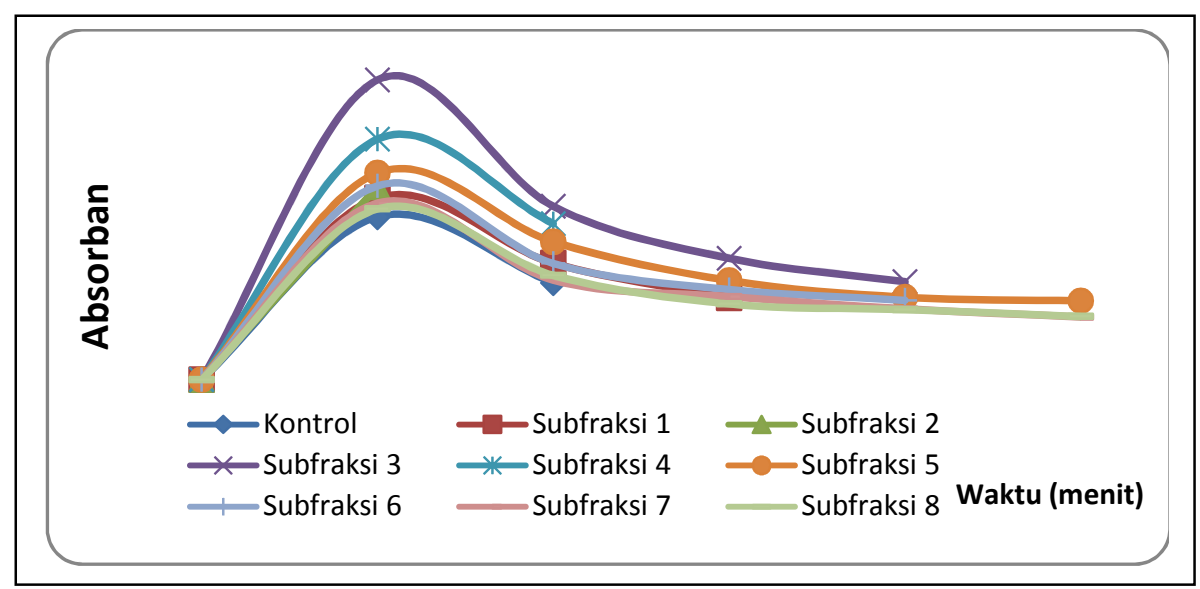

Gambar 4. Grafik indeks fagositosis dari darah mencit putih setelah pemberian Subfraksi meniran (Phylanthus niruri Linn.) selama 6 hari 
Data pada gambar 10 memperlihatkan peningkatan nilai indeks fagositosis rataratauntuk dosis tunggal $100 \mathrm{mg} / \mathrm{kgBB}$ pada masing-masing kelompok subfraksi 1, subfraksi 2, subfraksi 3, subfraksi 4, subfraksi 5 , subfraksi 6 , subfraksi 7 dan subfraksi 8 yaitu lebih besar dari satu (IF>1). Hal ini berarti pada setiap kelompok subfraksi meniran mempunyai kemampuan meningkatkan sistem pertahanan tubuh terhadap aktivitas fagositosis sel fagositik ${ }^{32}$.

Dari hasil uji statistik menggunakan analisis variansi satuarah terlihat bahwa dosis tunggal $100 \mathrm{mg} / \mathrm{kg}$ BB dari masing-masing kelompok subfraksi perlakuan terhadap kontrol tidak berbeda nyata $(\mathrm{P}>0,05)$. Hal ini berarti kemampuan fagositosis kedelapan kelompok subfraksi tersebut tidak berbeda jauh. Berdasarkan nilai rata-rata indeks fagositosis tiap subfraksi yang diberikan pada dosis tunggal $100 \mathrm{mg} / \mathrm{kgBB}$ yang diberikan, terlihat bahwa efek imunostimulan yang paling optimal diberikan oleh kelompok subfraksi 3 dosis $100 \mathrm{mg} / \mathrm{kgBB}$.

Pada penghitungan sel leukosit dengan metoda hapusan darah menggunakan larutan Giemsa sebagai pewarna, kemudian menggunakan minyak emersi sebagai penjelas bentuk sel leukosit terlihat sel neutrofil batang, sel eusinofil, sel monosit, sel neutrofil segmen, dan sel limfosit ${ }^{33}$. Sedangkan sel basofil yang bersifat basa tidak dapat diamati karena sel ini larut dalam pewarna Giemsa.Hasil perhitungan jumlah sel leukosit darah mencit dputih dapat dilihat Gambar 5.

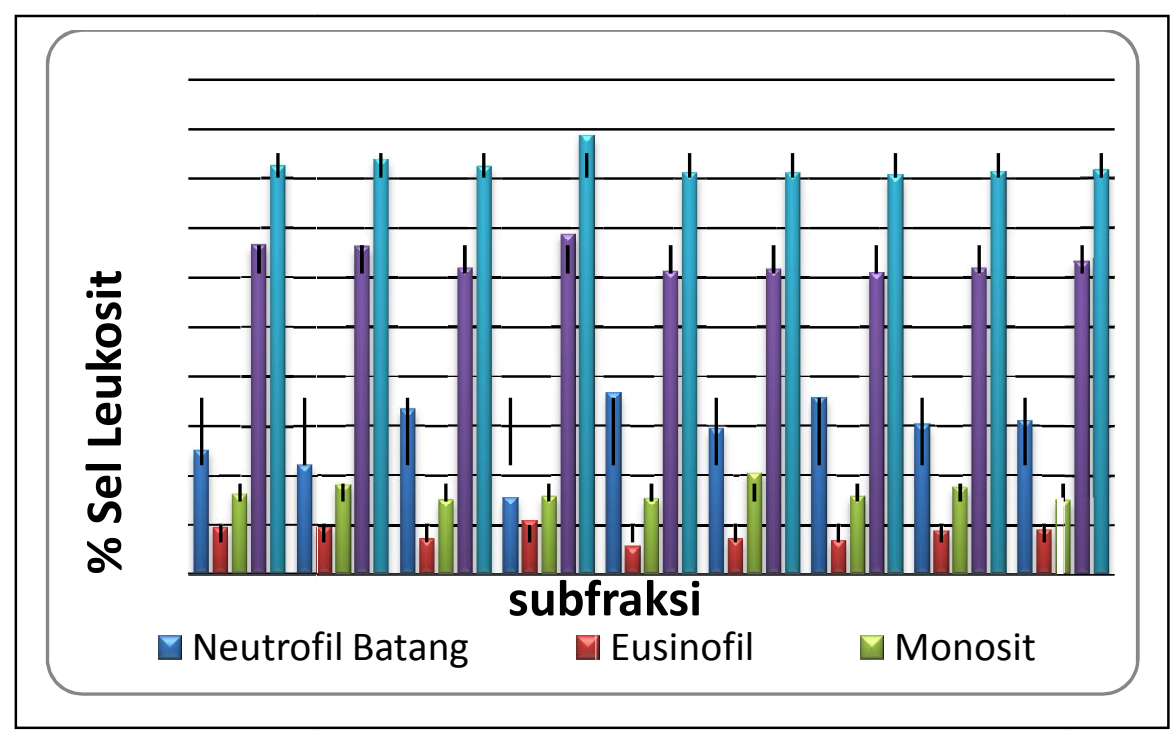

Gambar 5. Grafik persentase komponen sel leukosit darah mencit putih jantan terhadap subfraksi meniran (Phylanthus niruri Linn.) selama 6 hari secara oral dengan metoda hapusan darah.

Dari hasil uji statistik menggunakan analisis variansi satu arah, terlihat bahwa efek dosis tunggal $100 \mathrm{mg} / \mathrm{kgBB}$ beberapa kelompok subfraksi perlakuan terhadap kontrol berbeda secara nyata $(\mathrm{P}<0,05)$ pada setiap kelompok subfraksi untuk sel neutrofil batang, 
eusinofil, neutrofil segmen, dan limfosit, sedangkan tidak berbeda nyata untuk sel monosit. Setelah dilakukan uji lanjut dengan uji berjarak duncan terlihat bahwa pada sel eusinofil, sel neutrofil batang, limfosit dan sel neutrofil segmen terdapat perbedaan yangbermakna antara masing-masing kelompok subfraksi.

Pengujian uji respon imun spesifik dilakukan dengan menimbang bobot limpa dan penghitungan jumlah sel limfosit pada limpa mencit $^{34}$. Limpa merupakan tempat pembentukan limfosit yang digiatkan untuk masuk ke dalam darah. Limpa bereaksi terhadap antigen yang terbawa darah dan merupakan organ pembentukan antibodi. Hasil penimbangan bobot limpa dan bobot limpa relatif beberapa subfraksi meniran dapat dilihat pada Gambar 6 .

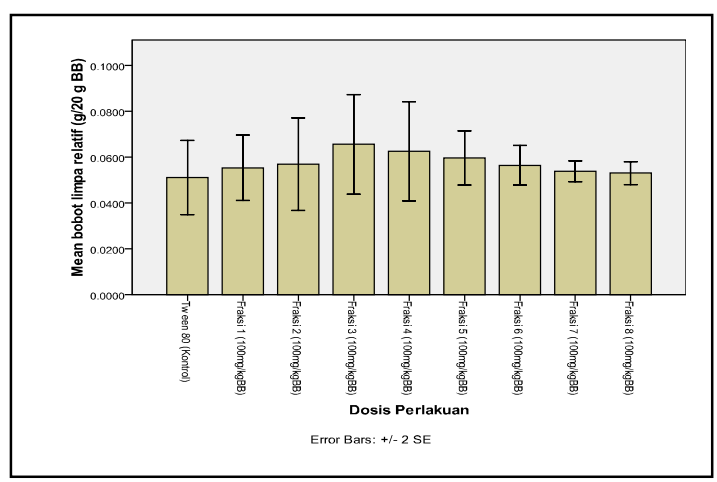

Gambar 6. Grafik bobot limpa relatif terhadap kelompok subfraksi meniran (Phylanthus niruri Linn.) pada mencit putih jantan setelah pemberian subfraksi selama 6 hari

Setelah dilakukan analisis statistik menggunakan anova satu arah, terlihat peningkatan tersebut tidak mempengaruhi bila dibandingkan dengan kontrol $(\mathrm{P}>0,05)$.

Hasil tersebut menunjukkan kenaikan bobot limpa relatif pada dosis tunggal $100 \mathrm{mg} / \mathrm{kg}$ dengan beberapa kelompok subfraksi perlakuan. Peningkatan terjadi berturut-turut pada dosis tunggal $100 \mathrm{mg} / \mathrm{kgBB}$ kelompok subfraksi 8, subfraksi 7, subfraksi 1, subfraksi 6, subfraksi 2, subfraksi 5, subfraksi 4, dan subfraksi 3. Dari hasil uji duncan dapat dilihat bahwa bobot limpa pada kelompok kontrol, dosis tunggal 100 $\mathrm{mg} / \mathrm{kgBB}$ subfraksi 3 , subfraksi 4 , subfraksi 5, subfraksi 2, subfraksi 6,subfraksi 1, subfraksi 7, dan subfraksi 8 tidak berbeda nyata satu sama lain. Hal ini berarti semakin meningkatnya bobot limpa maka semakin tinggi sel fagositik yang dihasilkan dalam pembentukan antibodi.Peningkatan optimal didapat pada dosis $100 \mathrm{mg} / \mathrm{kgBB}$ kelompok subfraksi 3.

Pada penghitungan jumlah sel limfosit limpa terjadi peningkatan jumlah sel yang ditunjukkan oleh persentase kenaikan jumlah sel limfosit pada setiap kelompok subfraksi. Hasil selengkapnya dapat dilihat pada Gambar 7. Berdasarkan analisis statistik terlihat bahwa efek dosis perlakuan terhadap kontrol berbedasecara nyata $(\mathrm{P}<0,05)$. Peningkatan sel limfosit limpa diperoleh berturut-turut pada dosis tunggal $100 \mathrm{mg} / \mathrm{kg}$ BB pada kelompok subfraksi 8 , subfraksi 7 , subfraksi 1, subfraksi 6, subfraksi 2, subfraksi 5, subfraksi 4, dan subfraksi 3. Dari hasil uji lanjutan menggunakan uji berjarak duncan dapat diketahui bahwa dosis tunggal $100 \mathrm{mg} / \mathrm{kg}$ BB subfraksi 3 berbeda nyata dengan subfraksi 4, subfraksi 5. Hasil selengkapnya dapat dilihat pada Gambar 7. 


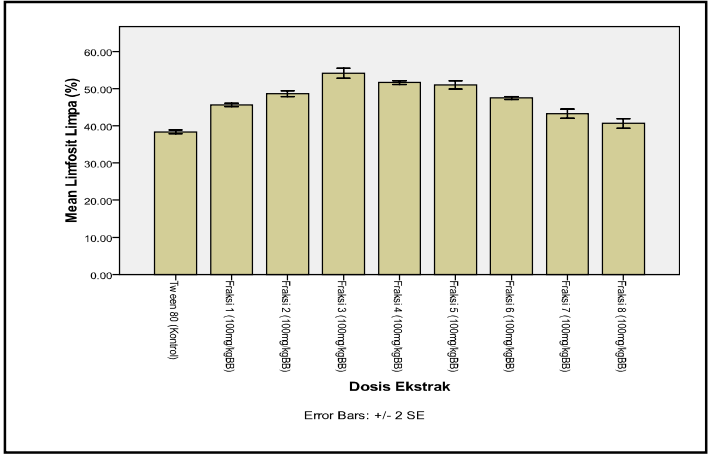

Gambar 7. Grafik persen sel limfosit limpa terhadap kelompok subfraksi meniran (Phylanthus niruri Linn.) pada mencit putih jantan setelah pemberian ekstrak selama 6 hari

Dari data diatas didapatkan dosis tunggal 100 $\mathrm{mg} / \mathrm{kgBB}$ subfraksi optimal yang dapat meningkatkan jumlah sel limfosit limpa yaitu kelompok subfraksi 3 dosis $100 \mathrm{mg} / \mathrm{kgBB}$.

Peningkatan jumlah sel limfosit pada limpa juga berarti peningkatan pula pada respon imun spesifik. Sel limfosit terdiri dari sel limfosit B dan sel limfosit T. Sel limfosit B akan mengalami proliferasi dan diferensiasi membentuk sel plasma dan sel memori. Sel plasma inilah yang membentuk antibodi yang terbentuk setelah kontak dengan antigen. Untuk membentuk antibodi, sel plasma perlu melakukan kerja sama dengan sel limfosit $\mathrm{T}$ (sel T-helper) ${ }^{4,35}$.

Ditinjau dari keempat parameter uji, yaitu kecepatan fagositosis, peningkatan jumlah sel leukosit darah, peningkatan bobot limpa dan bobot limpa relatif, serta peningkatan jumlah sel limfosit limpa, diketahui bahwa subfraksi 3 meniran yaitu dengan perbandingan subfraksi $n$-heksan:etil asetat (9:1) dosis $100 \mathrm{mg} / \mathrm{kgBB}$ memiliki aktivitas imunostimulant paling tinggi.

\section{KESIMPULAN}

Dari penelitian yang telah dilakukan dapat

diambil kesimpulan sebagai berikut:

1. Pemberian subfraksi meniran dengan dosis tunggal $100 \mathrm{mg} / \mathrm{kg}$ BB pada subfraksi 1, subfraksi 2, subfraksi 3, subfraksi 4, subfraksi 5, subfraksi 6, subfraksi 7, dan subfraksi 8,dapat meningkatkan aktivitas imunostimulanpada mencit putih jantan.

2. Uji respon imun nonspesifik dengan metoda bersihan karbon (carbon clearance) memberikan efek optimal pada $\begin{array}{llllll}\text { subfraksi } & 3 & \text { dosis } & 100 & \mathrm{mg} / \mathrm{kg} & \mathrm{BB}\end{array}$ Sedangkan dengan metoda penghitungan jumlah komponen sel leukosit darah, menunjukkan perbedaan secara nyata pada sel limfosit, eusinofil, dan neutrofil segmen pada semua kelompok subfraksi $(\mathrm{P}<0,05)$.

3. Uji respon imun spesifik dengan metoda penimbangan bobot limpa dan bobot limpa relatif menunjukkan efek optimal pada subfraksi 3 dosis $100 \mathrm{mg} / \mathrm{kg}$ BB $(\mathrm{P}>0,05)$. Sedangkan dengan metoda penghitungan sel limfosit limpa juga memberikan hasil optimal pada subfraksi 3 dosis $100 \mathrm{mg} / \mathrm{kg} \mathrm{BB}(\mathrm{P}<0,05)$.

\section{SARAN}

Disarankan kepada peneliti selanjutnya untuk meneliti pengaruh pemberian subfraksi meniran terhadap sitokin yang mempengaruhi aktivitas fagositosi 


\section{DAFTAR PUSTAKA}

1. Bellanti, J.A. 1993. Immunologi III. Washington. D.C: Georgetown University School of Medicine.

2. Baratawidjaja, K.G. dan Rengganis, I. 2009.Imunologi Dasar,Edisi VIII. Jakarta: Penerbit Universitas Indonesia.

3. Burmester, G.R. and Pezzetto, A.P. 2003. Color Atlas of Immunology. New York: Thieme Stuttgart.

4. Kresno, S.B. 2007. Imunologi: Diagnosis dan Prosedur Laboratorium.Edisi IV, Cetakan ke-3. Jakarta: Penerbit Universitas Indonesia.

5. Heyne, K. 2001. (in Indonesian).Tumbuhan Berguna Indonesia/Useful Indonesian Plants].Jilid III. Penerjemah: Badan Litbang Kehutanan. Jakarta: Badan Litbang Kehutanan.

6. Anonim.2009. Marker Compounds of Select Ayurvedic Drugs.Arumbakam : CCRAS

7. Sudarsono.1998. Tumbuhan Obat Indonesia.Yogyakarta : Universitas Gadjah Mada.

8. Darwin, E. 2006.Imunologi dan infeksi. Padang; UNAND Press

9. Hariana, A. 2007.Tumbuhan Obat dan Khasiatnya. Seri I. Jakarta: Penebar Swadaya.

10. Anonim.2007. Master Document Phyllanthus amarus.Bangalore : Dept. Quality Control Natural Remedies.

11. Sjahrurachman, A., Sukmana, N., Setiati, S., Munazir, Z., Rubiana, H., Nelwan, Lesmana dan Dianiati.2004. Pemberian Terapi Imunomodulator Herbal.Jurnal HTA Indonesia, 37-40.

12. Francisco, A., Bonilla., Raif, S. and Geha. 2005. Are You Immunodeficient?.Journal of Allergy and Immunology.

13. Murugaiyah, V., Chan, K. 2009. Mechanisms of Antihyperuricemic Effect of Phyllanthus niruri and its Lignan Constituents. Journal of Ethnopharmacology.University Sains Malaysia.

14. Sharma, Priyanka, Parmar, Jyoti, Verma, Preeti, Goyal, PK. 2009. Anti-tumor Activity of Phyllanthus niruri (a Medicinal Plant) on Chemical-induced Skin Carcinogenesis in Mice.Asian Pacific Journal of Cancer Prevention, Vol $10: 1-6$.

15. Anonim. 2011.Meniran dan Ragam Informasinya. Diakses tanggal 12 April 2013.http:/

www.diarypengetahuan.blogspot.com.
16. Anonim. 2012. Extraction Technologies for Medicinal and Aromatic Plants. Trieste, Italy : ICS-UNIDO.

17. Taylor. L. 2003. Herbal Secrets of the Rainforest, $\left(2^{\text {nd }}\right.$ ed.), Sage Press, Inc.

18. Udupa, A.L. 2010. Diuretic activity of Phyllanthus niruri (Linn.) in rats. HEALTH Vol.2, No.5, 511-512.

19. Rinki, Sonkar. 2011. Imunomodulatory Activity of Triphala Megaext.International Journal of Research in Pharmaceutical and Biomedical Sciences. Vol 2 (2).Sagar Institute of Pharmaceutical Sciences.

20. Mathur, R. 2011. Antimicrobial Effect of Phyllanthus niruri on Human Pathogenic Microorganisms.International Journal of Drug Discovery and Herbal Research 1(4) : 234-238.

21. Kashaw V., Nema1, Amit K., Agarwal, Abhinav. 2011. Hepatoprotective Prospective Of Herbal Drugs and Their Vesicular Carriers-A Review. International Journal of Research in Pharmaceutical and Biomedical Sciences vol. 2: 1-15. India

22. Aminul I., Selvan T., Mazumder U.K, and Ghosal S. 2008. Antitumour Effect Of Phyllanthin and Hypophyllanthin From Phyllanthus amarus Against Ehrlich Ascites Carcinoma In Mice. Pharmacologyonline 2: 796-807.

23. Harbone, J.B. 1987. Metode Fitokimia, Penuntun Cara Modern Menganalisa Tumbuhan (Edisi II). Bandung: Penerbit ITB.

24. Thompson, E.P. 1990. Bioscreening of drug, evaluation technique \& pharmacology. New York: Weinheim Basel Cambridge

25. Anief M. 1995. Ilmu Meracik Obat, Teori dan Praktik. (Ed.V). Yogyakarta: Gadjah Mada University Press.

26. Irawan, D. W. 2011. Pengaruh Phyllanthus niruri L (Flavonoid) Pada Sistem Imun Tubuh .(Skripsi). Yogyakarta: Fakultas Farmasi Universitas Ahmad Dahlan.

27. Jindal, S.K. 2004. Immunostimulation, Does it works in COPD?.CHEST Journal,126, 5,1406-1408.

28. Kusmardi, Kumala, S. danTriana., E.E. 2007. Efek Imunomodulator Ekstrak Daun Ketepeng Cina (Cassia alata L.) Terhadap Aktivitas dan Kapasitas Fagositosis Makrofag.Makara Kesehatan, 11, 2, 50-53.

29. Wagner, H. and Jurcic. K. 1991. Assay for Immunomodulation and Effect on Mediator of Inflamation.Methods Inflant Biochemistry.Vol 6.ISBN.201-202.

30. Wirawan, S.dan Erwin, S. 1996. Pemeriksaan Laboratorium Hematologi 
Sederhana. Edisi II. Jakarta: Fakultas Kedokteran Universitas Indonesia.

31. Nurliyani, Wayan, T.A. and Zuheid, N. 2005. Respon Antibodi dan Aktivitas Fagositosis Makrofag Peritoneal Mencit yang Diberi Protein Susu Kuda Pasteurisasi dan Fermentasi. Media Kedokteran Hewan, 21, 2, 51-57.

32. Yogendrasinh, Sunita, Solanki, Jain, M. 2010. Immunomodulatory Activity of Ayurvedic Plant Aparajita (Clitoria Ternatea L.)In Male Albino Rats.Global Journal of Science Frontier Research vol. 10 : 1-10.
33. Zlabinger,G.J., Nohammer, C., Bohmig, G.A., dan Menzel,J.E. 1994. Mode of action in immune cells. Journal of Cancer Research Clinical Oncology, 120,17-18.

34. Thakur, Mayank, B., Shilpi and Dixit, V. K. 2006.Immunomodulatory Activity of Chlorophytum borivilianum Sant. F. India : Department of Pharmaceutical Sciences, Dr H.S. Gour Vishwavidyalaya, Sagar, Madhya Pradesh.

35. Virella, G. 2007. Medical imunologi.(6th edition). New York: Informa Healthcare USA Inc. 